NASZA DERMATOLOGIA Onlin OUR DERMATOLOGY Online

Source of Support: Nil

Competing Interests: None

\section{NAMES OF „LINES” IN DERMATOLOGY LITERATURE}

\author{
Khalid Al Aboud ${ }^{1}$, Ahmad Al Aboud ${ }^{2}$ \\ ${ }^{1}$ Department of Public Health, King Faisal Hospital, Makkah, Saudi Arabia \\ ${ }^{2}$ Dermatology Department, King Abdullah Medical City, Makkah, Saudi Arabia
}

Corresponding author: Dr. Khalid Al Aboud

amoa65@hotmail.com

The aim of this communication is to shed some lights on the names of some of the „lines” encountered in dermatology, which are summarized in Table I.

\begin{tabular}{|c|c|}
\hline $\begin{array}{l}\text { Names of "Lines", in } \\
\text { dermatology literature }\end{array}$ & Remarks \\
\hline AA lines [1] & $\begin{array}{l}\text { Linear, slightly depressed transverse line of the upper part of the forearm. Named by } \\
\text { the team who reported it as AA (antecubital Ahn's) lines. Ahn is the first author of the } \\
\text { report. }\end{array}$ \\
\hline Beau's lines [2] & $\begin{array}{l}\text { Beau's lines are deep grooved lines in the nails. They are named after, a French } \\
\text { physician, Joseph Honoré Simon Beau (1806-1865), who first described it in } 1846 \text {. }\end{array}$ \\
\hline Bunny lines [3] & $\begin{array}{l}\text { Bunny lines are the subtle crinkly wrinkles on both sides of the nose. They get their } \\
\text { name from the cute way bunnies scrunch up their noses. }\end{array}$ \\
\hline $\begin{array}{l}\text { Futcher's lines or Voigt's lines or } \\
\text { Futcher-Voigt's lines or Ito lines } \\
\qquad[4,5]\end{array}$ & $\begin{array}{l}\text { These are less common names for what is known as Pigmentary demarcation } \\
\text { lines (PDL). PDL are physiological abrupt transition lines from areas of deeper } \\
\text { pigmentation to the area with less pigmentation. Five types (A-E) have been described. } \\
\text { More recently; facial lines F, G and H were added. Type A (Futcher's / Voigt's lines), } \\
\text { the most common lines, seen over the dorso-ventral aspect of the arms. These lines } \\
\text { are named after Howard Palmer Futcher (1910-2004), (Fig. 1) an American-Canadian } \\
\text { physician. He was the former member of the faculty of the Johns Hopkins University } \\
\text { School of Medicine, executive director of the American Board of Internal Medicine. }\end{array}$ \\
\hline
\end{tabular}




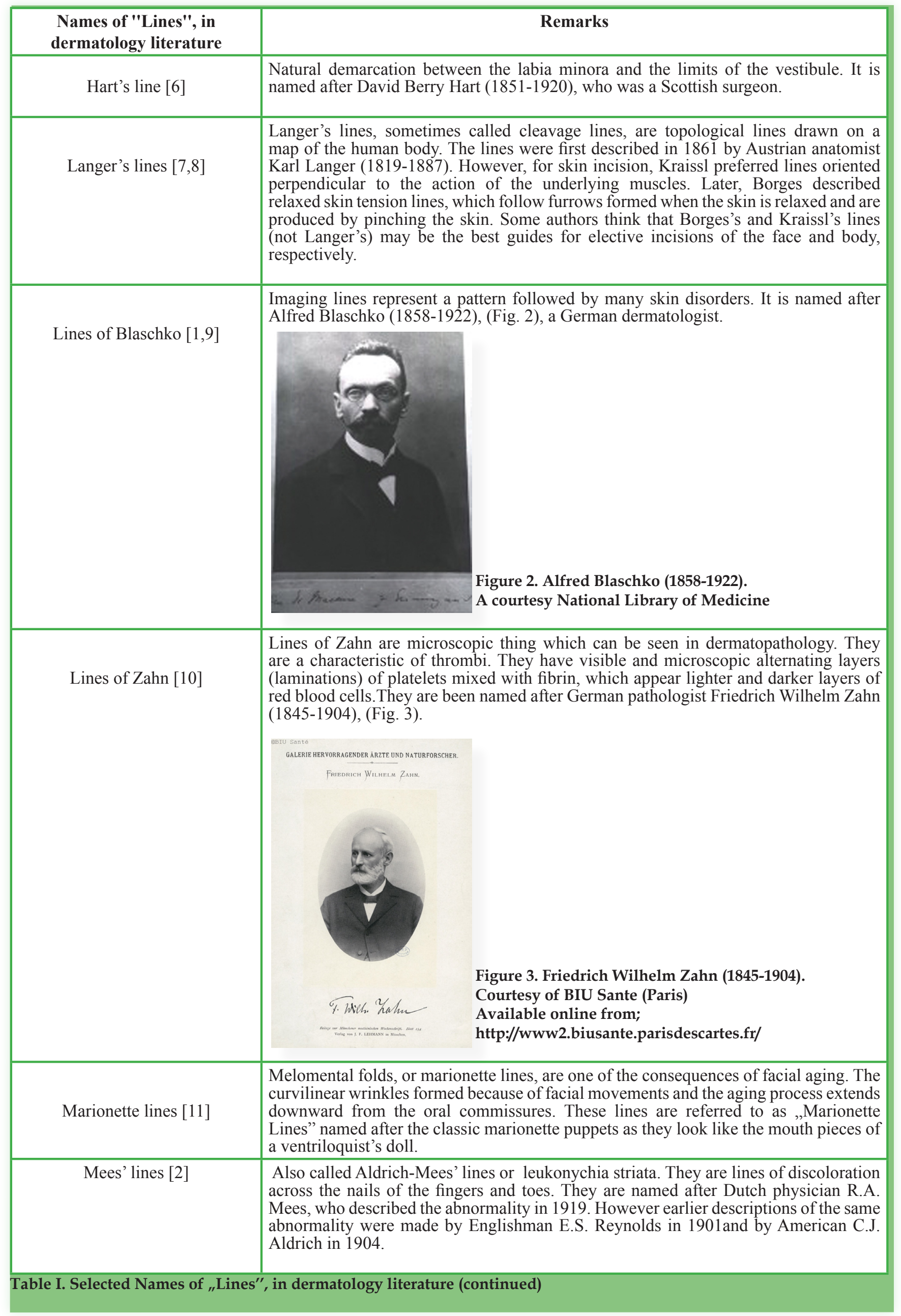




\begin{tabular}{|c|c|}
\hline $\begin{array}{c}\text { Names of "Lines", in } \\
\text { dermatology literature }\end{array}$ & \multicolumn{1}{c|}{ Remarks } \\
\hline Muehrcke lines [2] & $\begin{array}{l}\text { Muehrcke's lines are white lines (leukonychia) that extend all the way across the nail } \\
\text { and lie parallel to the lunula. Muehrcke's lines were described by Robert C. Muehrcke } \\
(1921-2003), \text { an American Physician in 1956. }\end{array}$ \\
\hline Pastia's line [12] & $\begin{array}{l}\text { Transverse red streaks in the skin folds due to capillary fragility in patients with scarlet } \\
\text { fever it is named after a Romanian physician, Constantin Chessec Pastia (1883-1926). }\end{array}$ \\
\hline Table I. Selected Names of "Lines", in dermatology literature (continued) \\
\hline
\end{tabular}

\section{REFERENCES}

1. Ahn SK, Kim SJ, Choi EH, Lee SH, Lee S: AA line. Int J Dermatol. 1998;37:190-3.

2. Al Aboud K . Eponyms in dermatology literature linked to Nails. Our Dermatol Online. 2012;3:378-80.

3. Raspaldo H, Baspeyras M, Bellity P, Dallara JM, Gassia V, Niforos FR, et al: Consensus Group. Upper- and mid-face anti-aging treatment and prevention using onabotulinumtoxin A: the 2010 multidisciplinary French consensus--part 1. J Cosmet Dermatol. 2011;10:36-50.

4. Brzeziński P, Gijón EG, López-López J, Toyokawa T, Scrimshaw NS, Malard O, et al: Dermatology Eponyms-Phenomen/SignLexicon (F).Our Dermatol Online. 2012;3:66-78.

5. Ito $\mathrm{K}$ : The peculiar demarcation of pigmentation along the so-called Voigt's line among the Japanese. Dermatologia Int. 1965;4:45-7.
6. Obituary: David Berry Hart, M.D., F.R.C.P.Edin. Br Med J. 1920;19:852-3.

7. Wilhelmi BJ, Blackwell SJ, Phillips LG: Langer's lines: to use or not to use. Plast Reconstr Surg. 1999;104:208-14.

8. Gibson T: Karl Langer (1819-1887) and his lines. Br J Plast Surg. 1978;31:1-2.

9. Kleine-Natrop HE: [50th anniversary of Alfred Blaschko's death]. Dermatol Monatsschr. 1972;158:846.

10. Benaroyo L: [Contribution of Friedrich Wilhelm Zahn (18451904) to the study of inflammation]. Gesnerus. 1991;49:395-408.

11. Carruthers A, Carruthers J, Hardas B, Kaur M, Goertelmeyer $\mathrm{R}$, Jones $\mathrm{D}$, et al: A validated grading scale for marionette lines. Dermatol Surg. 2008;34Suppl 2:S167-72.

12. Marcu N: [The life and activity of Dr. Constantin C. Pastia (18831926)]. Rev Ig Bacteriol Virusol Parazitol Epidemiol Pneumoftiziol Bacteriol Virusol Parazitol Epidemiol. 1983;28:89-95. 